\title{
THE CAUSE OF HUGE LOSS TO CUSTOMER IN ONLINE SHOPPING CASE STUDY IN INDONESIA
}

\author{
Rahmat Taufiq Dwi Jatmika, Universitas Suryakancana, Jl. Pasirgede Raya Bojongherang Cianjur, Jawa \\ Barat, Indonesia
}

Nurjaya, Universitas Suryakancana, Jl. Pasirgede Raya Bojongherang Cianjur, Jawa Barat, Indonesia Anggun Tri Sukma Utami, Universitas Suryakancana, Jl. Pasirgede Raya Bojongherang Cianjur, Jawa Barat, Indonesia

\section{dx.doi.org/10.18374/IJBS-21-1.5}

\begin{abstract}
The development technology has an impact on changing offline to online shopping or we usually called e-commerce which has offered many conveniences. However, e-commerce can also cause consumer loss. Consumer losses can occur due to seller cheating. The objective of this research is to Identifying customer protection in Online Shopping, Identifying how far the customer protected from the seller that cheating, Offering improvement solution and recommendation for the customer about customer protection using online shop. This study will conduct mixed method using qualitative and quantitative method. Qualitative method will use structured and unstructured interviewing. For the quantitative method will use questionnaire towards the respondent. Thus the result will be analysis based on data and the answer of this method. The results showed that information in e-commerce such as product specifications, comments and other consumer assessments become the main information for consumers. Producers who provide information to the target market will influence consumer judgment in buying what the company sells. Providing detailed information can also be an effort to protect consumers from consumer misunderstanding or from the seller that cheating. The result of consumer protection from the seller are to provide detailed information about the product, introduced the new product to buyer continuously to consumers and carry out after-sales services that meet consumer desires. Meanwhile, the result for the consumer side is must critical about the information the company provides before buy it, use chat, comment and rating column for consider to buy the things and ask near people about the things.
\end{abstract}

Keywords: Customer, Online Shopping, E-Commerce, Cunsumer Protection. 